\title{
Theory of Global Sustainable Development Based on Microalgae in Bio and Industrial Cycles, Management-Changing Decisions in Areas of Climate Change and Waste Management
}

\author{
Armen B. Avagyan \\ Research \& Industry Centre of Photosynthesizing Organisms, Feed Additives and \\ Physiologically Active Compounds, Yerevan, Armenia \\ Email: armin.av@hotmail.com
}

Received May 22, 2013; revised June 14, 2013; accepted July 6, 2013

Copyright (C) 2013 Armen B. Avagyan. This is an open access article distributed under the Creative Commons Attribution License, which permits unrestricted use, distribution, and reproduction in any medium, provided the original work is properly cited.

\begin{abstract}
The paper provides requested management-changing decisions through implementation of conclusions of Global Sustainable Development theory based on including of microalgae in Bio and Industrial Cycles in the area of waste-related management challenges within creating market opportunities for industry through expansion of resource efficiency use across global supply chains and new design and building sustainable development with contemporary manufacturing of value added products. A truly coherent waste management and other production policy (biofuel, biopharmaceuticals, food, feed and perfumery additives) and mitigation of Climate Change are ways to bring these traces closer to cost effective manufacturing, improving of resource efficiency use, well being economy and human health. Offered technological change dramatically increase biomass feedstock resources, reduce waste origin of greenhouse emission (since $13 \%-17 \%$ ), organics sent to landfill, pyrolyses, etc. and create a model that all elements along the waste value chain create economic, societal and/or environmental value.
\end{abstract}

Keywords: Microalgae; Global Sustainable Development; Climate Change; Waste Management; Biofuel; Feed and Perfumery Additives; Biopharmaceuticals

\section{Introduction}

Today waste conversion is one of nowadays viable answers to the waste problem spreading over the World [14]. Waste management practices impact on greenhouse gas (GHG) emissions by affecting energy consumption, methane generation, carbon sequestration, and non-energyrelated manufacturing emissions [5-7]. Policymakers, managers and scientists need to recognize that ecosystems reduce their ability to deliver the benefits which we need and ecosystems provide [4]. Biotechnology and industry should play an important role in effectively addressing the unsustainable exploitation of waste resources around the world by addressing its own first priorities and values, and must participate in the development of alternate innovation methodologies and technologies that make environmental and industrial projects more adaptable, sustainable and robust in order to respond to a range of possible future scenarios.
Motivation is a kind of basic function of management, because without motivation, innovative idea cannot work effectively. Adaptive management strategies and biotechnology allow of changing course based on new insight, help to establish and sustain institutional settings and technological systems that are flexible and error-tolerant. The biotechnological management game-changing decisions are offered in the book "Theory of Global Sustainable Development based on including microalgae in Bio and Industrial Cycles. New Design and Building of Biological System", which described also ways of innovation management of waste through increasing of resource efficiency use across global supply chains, building of products and technology roadmaps, posing new questions for investigation, generating new connections among old facts, and finding of new environments in which transformational solutions of the Global challenges were proliferated [1]. A truly biotechnological waste processing 
and other production policies are ways to bring these traces closer to cost effective manufacturing, well being economy, improving of resource efficiency use and human health. Therefore this paper addressed to how to design, build and operate the waste management and manufacturing of value added products by the use of microalgae linked to Global Sustainable Development and mitigation of Climate change.

\section{Discussion}

\subsection{Waste Management}

In 2011 the world generated 2 billion tons of municipal solid waste (MSW) [8] Europeans share is approximately 265 million tons of MSW in 2012 and globally the production of MSW will rise from the current 1.3 to 2.2 billion tones (the annual cost of solid waste management is projected to rise from the current $\$ 205$ billion to $\$ 375$ billion in 2025 per year) [9]. A significant fraction of MSW consists of organic bio-waste (biological origin and biodegradable), estimated at a total of up to about $140 \mathrm{Mt}$ of which up to $37 \mathrm{Mt}$ originates from the food and drink industry [10]. The bio-waste technologies convert such biodegradable waste to humus via composting, energy via anaerobic digestion, biodiesel or ethanol via fuel conversion, or fertilizer through pyrolyses. The EPA reports, covering of this waste generation from 1960 up to 2009 , showed that average person produced $1.96 \mathrm{~kg}$ per day of biowaste [2] and the U.S. generated 243 million tons of MSW in 2009, 250 million tons in 2010 [3]. A total of 61.3 million tons of municipal waste was recycled, while 20.8 million tons of organic waste composed. In 2010, Americans generated about of trash and recycled and composted over 85 million tons equivalent to a 34.1 percent recycling rate. In addition, $11.9 \%$ (29 million tons) of this waste was incinerated in Waste-to-Energy (WtE) facilities. Meanwhile landfill accounted for 131.9 million tons, or $54.3 \%$. Europeans incinerated 69.5 million tons of MSW per year between 2007 and 2010 [11].

In May 9, 2013 the daily mean concentration of $\mathrm{CO}_{2}$ in the atmosphere of Mauna Loa, Hawaii, surpassed 400 parts per million (ppm) for the first time since measurements began in 1958 (in the middle of the XIX century concentration of carbon dioxide in the atmosphere was about $280 \mathrm{ppm}$ ) [12] which confirm that we must to account unforeseeable changes in the nature. According to the EPA solid waste are largest source of GHG emissions of landfill methane $\left(\mathrm{CH}_{4}\right)$, followed by wastewater $\mathrm{CH}_{4}$ and nitrous oxide $\left(\mathrm{N}_{2} \mathrm{O}\right)$ (3\% of 2004 emissions) [13]. Canada has highest level of municipal waste generation per capita (above $800 \mathrm{~kg}$ ) in comparison with other developed countries and its total GHG emissions estimated to 702 megatons $\mathrm{CO}_{2}$ equivalent $\left(\mathrm{Mt} \mathrm{CO}_{2} \mathrm{Eq}\right)$, an increase of approximately $1 \mathrm{Mt}(0.14 \%)$ from the 2010 level of $701 \mathrm{Mt}$ [14]. Landfills face more stringent regulation of $\mathrm{CH}_{4}$ collection, and incineration is hindered by increasingly tough regulations on emissions. What kinds of biotechnological approach are relevant in this context to deal with new types of risks and opportunities? This requires more in-depth analysis, which might touch upon factors such as the type of policy in use, management design, non-economic barriers, resource intensity and technology demand for set realistic expectations of policy outcomes.

The perception that landfills are not a viable long term option has driven incentives towards renewable energy and waste management. WtE facilities are integrated into broader waste management regimes aimed at preventing the use of landfills and as an attractive technology option to promote low carbon growth in the crowded renewable energy landscape through the capture of $\mathrm{CH}_{4}$, which is a naturally occurring by-product of the decomposition of waste in a landfill or the anaerobic digestion of sewage sludge. Organic matter converts ultimately to $\mathrm{CH}_{4}(65 \%)$, $\mathrm{CO}_{2}(35 \%)$ and power [15-17] and their market is set to be worth $\$ 26$ bn by 2016 [16]. However since 2006 up to 2010 approximately $95 \%$ of the global WtE market was accounted only two technologies: incineration and anaerobic digestion [18]. Although combustion technologies continue to lead the market, advanced thermal treatment technology deployments such as pyrolysis are expected to pick up as diminishing landfill capacity improves WtE economics. Pyrolysis, plasma gasification, and gasification are expected to gain relative market share and together will comprise over $30 \%$ of the total $\mathrm{WtE}$ market by 2015 . While more than 800 thermal $\mathrm{WtE}$ plants currently operate in nearly 40 countries around the globe, these facilities treated just $11 \%$ of MSW generated worldwide in 2011 compared to the $70 \%$ that was landfilled [8]. WtE systems will treat at least 261 million tons of waste annually by 2022 , with a total estimated output of 283 terawatt hours (TWh) of electricity and heat generation is $221 \mathrm{TWh}$ in 2010, global market reaches from $\$ 6.2$ billion in 2012 up to $\$ 29.2$ billion by $2022[8,9]$. Under a more optimistic scenario, WtE can potentially treat 396 million tons of MSW per year with producing of 429 TWh of power.

What are the main bottlenecks to achieving of waste management objectives? Despite these greatly encouraging forecasts, there are a number of challenges facing the waste conversion industry. Public opinion plagues protested against some profiles of waste conversion technologies [19]. Such technologies as pyrolyses and gasification has a negative association with waste incineration, and people can be reluctant to have such projects situated close to them. The principal source of revenue from Methane Power's landfill gas to energy projects is 
the bundled sale of electricity and renewable energy certificates to local utilities. The pricing is entirely dependent upon the contractual terms that the company is able to negotiate with the relevant utility. The sale of carbon credits from eligible projects is another potential revenue stream and can destroy by a particular project. Simultaneously, the market price per ton of these credits can fluctuate greatly, relevant factors being the standard against which a project is verified and the market in to which the carbon credits are being sold. Current market pricing for carbon credits is at historic lows, and policy do not provide tax incentives or subsidies, making life uncomfortable for those whose business plan has been heavily carbon-credit focused $[8,20]$.

Biomass gasification technologies have been demonstrated and implemented successfully at large scale, but inefficiencies in the technology and other non-technical barriers render biomass gasification economically unviable in comparison to fossil-based energy [21]. Simultaneously, the speculative nature of many Waste-to-Biofuel projects has led to a lack of consensus over the most effective technologies and appropriate business model for conversion projects. Indeed financing these new and emerging technologies on a commercial scale is difficult in today's cautious financial environment and the end result is that only very few companies of waste conversion technologies reach full scale commercial viability [16]. Biogas producing is also a complex technological process that makes monitoring complicated [15]. However burning of $\mathrm{CH}_{4}$ (with generation as one of final product of $\mathrm{CO}_{2}$ ) is grounded that such product at 21 times less harmful by GNG indicator as decrease $\mathrm{CH}_{4}$ emission [22]. So, risk profiles of waste conversion technologies can be high, meaning project implementation is extremely hard. The EPA provided that more companies understand these uncertainties and risks [13]. In addition, $11.9 \%$, or 29 million tons of the U.S. waste was incinerated in $\mathrm{WtE}$ facilities, down from 31.6 million tons in 2006, less than 29.7 million tons estimated in 1990 [3]. The CEWEP Report check the possible effects of the main parameters of energy efficiency performance in the R1 formula (Recovery (R1) efficiency factor) with a view to gathering information for the determination of a possible climate factor and found that is met only $65.6 \%$ (206 WtE plants out of the total 314 investigated) [11]. The CEWEP explained that it is much more difficult to achieve the R1 threshold, in particular if plants are small and can only export electricity (often with little or no opportunity to export heat). The analysis pointed also to the fact that over $75 \%$ of Europe's 480 $\mathrm{WtE}$ facilities are more than ten years old and many will need modernizing to adhere to the current strict legal requirements, especially of flue gas treatment [23]. So, the industry is holding its' breath to see what will happen next. The challenges are clear: choosing the right technology for each company and then delivering an operational project cost effectively and at scale. What novel type of management, technological and economic approaches, systems design, policy, and stewardship can be used for effectively waste management through mitigation of waste landfilling, pyrolyses, methane and carbon manufacturing as well as increase effectiveness of wastewater cleaning?

\subsection{Microalgae Application for Management and Conversation of Waste}

The economics of biomass power generation are critically dependent upon the availability of a secure, longterm supply of feedstock at a competitive cost. The main question regarding the viability of biomass plants lies in the development of a reliable feedstock supply chain, especially because long-term feedstock agreements are essential for financing of any biomass project. Many biomass generation technologies are mature and are not likely to undergo significant technological change, while cost reductions through scale-up will be modest [24-26]. Potential bio-energy supply until 2050 up to $700 \mathrm{EJ} / \mathrm{yr}$ was estimate from marginal lands $(0-150 \mathrm{EJ} / \mathrm{yr})$, forest residues $(0-150 \mathrm{EJ} / \mathrm{yr})$ as well as relatively low potential can be found in residues from agriculture $(15-70 \mathrm{EJ} / \mathrm{yr})$, dry manure (5 - $55 \mathrm{EJ} / \mathrm{yr}$ ) and organic waste-only 5 - 50 $\mathrm{EJ} / \mathrm{yr}$ [27]. Can we increase feedstock resources through the use of waste?

The biological method stands out as most effective and economically efficient method for the purification of industrial and municipal wastewaters by using the microbiological activated sludge. However, bacteria of the activated sludge have low stability to high concentration of organic and mineral components, thus considering increased rate of water flow and also requires further destruction of superfluous quantity of activated sludge [1]. The application of microalgae for wastewater purifycation opened the possibility of alternative approaches as they expose higher stability which enables their use in more concentrated and toxic environments and obtain higher purification rate compared with activated sludge. Wastewater is also an attractive resource for algae production due to its nutrient content and low cost and coupled with an increased push to dramatically reduce organics sent to landfill, pyrolyses, and carbon manufacturing and can be the drive towards innovation waste management.

The U.S. Office of Fuels Development funded the Aquatic Species Program (ASP (NREL/TP-580-24190, 1978 - 1996, \$25 million)) aimed to develop technology on production of biodiesel from high lipid-content algae [28-30]. A major conclusion from the ASP analyses is that there is little prospect for any alternatives to the open 
pool designs for microalgae production, given low cost requirements associated with fuel production and the factors that most influence on cost are biological and not engineering-related, and the only plausible near to mid-term application of microalgae biofuels requires biomass manufacturing by integration with wastewater treatment. Two hundred thousand hectares (less than $0.1 \%$ of climatically suitable land areas in the U.S.) could produce one quad of fuel $(1.055 \times 1018 \mathrm{~J})$, approximately 9.5 million acres would be required to produce 15,000 gallons of oil per acre from algae. To produce would be required soybeans almost $3 \mathrm{bn}$ acres of soybeans fields, or over $1 \mathrm{bn}$ acres of canola fields at nominal yields of 48 and 127 gallons of oil per acre, respectively [31].

Recently it has been a greater focus on improving the management of water services by the use of microalgae, but how much impact archived in practice? Current many microalgae biofuel projects of Biofuel Digest databases are pilots and demonstrations as well as did not use the some recommendations of the ASP program in particular the use of wastewater for cost down $[1,32]$. The NASA presents its latest technology based on five square kilometers of plastic bags would be used to produce 2.4 million gallons of algae oil per year (today drop in the bucket compared to the 800 million gallons of oil the U.S. consumes every day). The setup has been tested in four nine-meter-long plastic bags and the researchers demonstrated that they can grow enough algae to produce nearly 2000 gallons of fuel per acre per year-if the weather cooperates. Those systems involve recycling human waste, but technological design will face many challenges addressed to industrial manufacturing [33]. Since 1950-1960 the U.S. Berkeley Energy Biosciences Institute (EBI) focused on combining municipal wastewater treatment with algae as the most plausible model for biofuels production in the near term. Their final analysis includes five conceptual facilities for algae pond biofuel production, four of them 250 acres in size and one of 1,000 acres [30]. The estimated capital costs for a 250 -acre biofuel production system emphasizing microalgae oil production are about $\$ 21$ million, with annual operating costs at around $\$ 1.5$ million, to produce about 12,300 barrels of oil, giving a break-even price per barrel of oil of $\$ 330$ (based on an 8 percent capital charge). Increasing the scale of the system to 1,000 acres reduced the break-even price to about $\$ 240$ per barrel. These prices considered wastewater treatment credits, which reduced costs about $20 \%$. Although, a significant number of combined algae wastewater treatment biofuels facilities could be located in the US (over 8000 existing municipal wastewater treatment ponds (several thousand small $(<10$ hectare) and a few large scale $(>100$ hectare)), their aggregate contribution to US liquid fuel resources would be minor-at best a small fraction of $1 \%$ of total
U.S. demand [30]. EBI scientists made following conclusion "that algal oil production will be neither quick nor plentiful -10 years is a reasonable projection for research, development and demonstration to allow a conclusion about the ability to achieve, at least for specific locations, relatively low-cost algal biomass and oil production, cultivate stable cultures under outdoor conditions while achieving both high productivities and oil content, bioflocculation for algae harvesting take in account including racewa pond for microalgae cultivation, and extraction of algae oil by the use of hexane".

What can we do if objectives are not met in proving or if progress is too slow? Can we design and implement new management models across the waste hierarchy, value chains and life cycles of products and processes to dramatically reduce waste generated in the world and increase biomass for value added product? What should be done for Global Sustainable development as open burning and open dumping of waste pose the biggest risks? What novel type of management, technological and economic approaches, systems design, policy, and stewardship can be used for effectively waste management through mitigation of waste landfilling, pyrolyses, methane and carbon manufacturing as well as increase effectiveness of wastewater cleaning?

Our findings on industrial wastewater provide that concentration of $\mathrm{N}$ and organic components of municipal wastewater are not sufficient for rapid accumulation combined with high yield of Chlorella biomass [1]. The second bottleneck on the use of municipal wastewater for manufacturing of microalgae biomass is limit the application of such biomass in some niches of market as municipal wastewater contains dissolved heavy metal which microalgae accumulate. Other bottlenecks are that municipal Wastewater Treatment Plant (WTP) biological ponds do not ensure optimal way for microalgae biomass producing as they are large, unmixed, and thus heterogeneous systems, where is no possibility to manage the algae culture and effective harvesting of biomass [30] and has big water flow. Based on our findings it offered apply integrally cascading steps for wastewater management with taking in the account that urban settlements which are also the main source of point source pollution with taking in account that technological development creates more consumer goods introducing new toxic and hazardous chemicals in urban wastewater [1]. Some of such synthetic chemicals that are found in wastewater pesticides and pharmaceuticals are endocrine disruptors [4]. The negative effects of these chemicals extend beyond the exposed individual, particularly affecting fetuses of exposed pregnant women and breastfed children. So, the waste management met global problem-indirect impact of on human health and environment numerous endocrine disruptors including unused and unwanted 
pharmaceuticals in the rivers, lakes, streams and drinking waters as the survey show that consumers tend to dispose a large part of their unwanted, unused and expired pharmaceuticals in garbage, toilets, and sinks. Therefore the developed countries exploit programs to better manage unused pharmaceuticals at health care facilities and pharmaceutical take-back programs [1,25,34-36]. However these programs are able to reduce the levels of pharmaceuticals entering in the environment only on $10 \%$ to $15 \%$ and pharmaceuticals can pass through sewage treatment plants and be released to the environment as WTP are, in general, not designed to remove such chemicals [34,37]. What kind of capacity and what risk prevention strategies are required to break the vicious circle? It is necessary to identify important wastewater management service provide for solving of this global problem and adaptation measures are needed urgently. Theory offer integrally apply cascading steps for wastewater management which Step 1 include cleaning of industrial wastewater or water solution of solid bio-waste contained high concentration of organic or toxic components in specialized installation up to degree meeting the requirements for its transfer to the municipal WTP and giving priority to the transformation of obtained microalgae biomass for producing of value added product; Step 2-use of postprocessing wastewater contained residual quantities of the microalgae for improvement treatment of wastewater by two following ways: 1) in biological ponds with saunter accumulation of microalgae biomass with further separation for value added product cycles (zero waste solution and zero activated sludge), 2) in aeration oxidation ponds of the industrial WTP (containing of high concentration of organic and toxic components) for creating of the symbiosis between bacteria of activated sludge and microalgae which is general way for improving management (Figure 1) [1]. Simultaneously, in addition it offer new cost-beneficial, ecologically safe game changing approach, which include destruction pharmaceuticals in water and next cleaning of solution by the use of above listed two Steps approach and giving priority to the transformation of obtained microalgae biomass for producing of value added products instead they expensive incineration at temperature above $1200^{\circ} \mathrm{C}$ in the special furnaces in order to prevent the pollution of atmosphere by toxic products of combustion (dioxins and chlorinated dibenzofurans) as well as the stack effluence including $\mathrm{HCl}, \mathrm{CO}, \mathrm{CO}_{2}, \mathrm{NO}_{\mathrm{x}}$ with conservation of fossil fuel etc. [1]. This approach based on our findings of high level cleaning of wastewaters of Yerevan Chemical Reagents, Yerevan Vitamin, Charensavan Lysine plants, etc. which content are above equivalent to the mixture of pharmaceuticals [1].

The question of what strategic approach we should

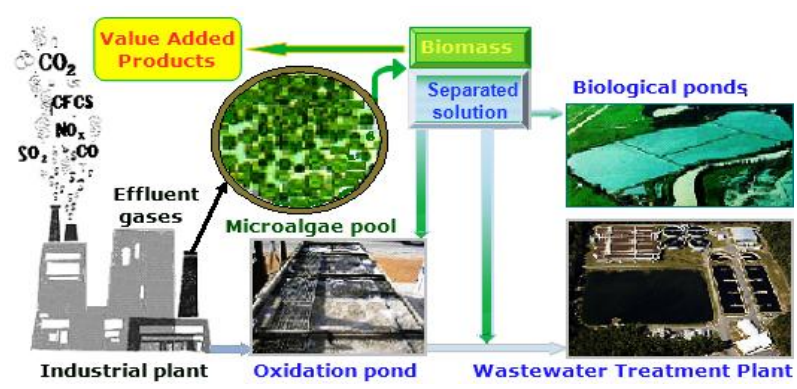

Figure 1. Vision on application of microalgae for purification of industrial wastewater and gas effluent as well as improvement municipal wastewater treatment in wastewater treatment plant.

take in order to pursue an international climate protection policy. With landfill finally being truly on the way out, there plan genuine opportunities for investment in valueadding solutions through reducing origin of GHG emission and their resource uses for producing value added products as well as mitigation of effluent gases. Roughly one-third of the edible parts of food produced for human consumption gets lost or wasted globally, which is about 1.3 billion ton per year [38]. Food waste is more a problem in industrialized countries, most often caused by both retailers and consumers throwing perfectly edible foodstuffs into the trash. Per capita waste by consumers is between 95 - $115 \mathrm{~kg}$ per year in Europe and North America. Simultaneously, food systems contribute 19\% $29 \%$ of global anthropogenic GHG emissions, releasing $9800-16,900 \mathrm{MtCO}_{2} \mathrm{Eq}$ in 2008. Incorporating thermal treatment solutions for MSW material can help waste management companies to turn waste material with limited recycling value into a valuable resource $[1,23]$. The thermal processing as thermal hydrolysis collected and watered municipal solid bio-waste (through the use of effluent gases of thermal power station, cement plants, etc.) may create additional raw material for manufacturing of microalgae biomass aimed to producing of value added products (mitigation of solid waste and origin for GHG emissions) with minimizing of landfilling, methane and carbon production GHG [1].

To help illustrate the potential for GHG reduction and avoidance opportunities from materials management practices with the use microalgae provide the following scenario. According EPA estimation the U.S. GNG emissions totaled $6702 \mathrm{MtCO}_{2} \mathrm{Eq}$ and the provision of food contributes $13 \%$ in 2011 [5,6,39]. Therefore the thermal hydrolyses of this biowaste allow they use as raw material for microalgae biotechnological manufacturing and can decrease GHG emissions up to 871.3 $\mathrm{MtCO}_{2} \mathrm{Eq}$. According to the European data the base-year emissions for the EU-15 is equivalent to 4,265.5 and for EU-12-132.6 $\mathrm{MtCO}_{2} \mathrm{Eq}[7,40]$. The EU food and drink value chain is responsible for $17 \%$ of direct GHG emission and $28 \%$ of 
material resource use $[41,42]$. Therefore application of their food scraps by offered technology will decrease GHG emissions up to $747.7 \mathrm{MtCO}_{2} \mathrm{Eq}$. Canada $\mathrm{GHG}$ emissions estimated to $702 \mathrm{MtCO}_{2} \mathrm{Eq}$ and food scraps share is $12.7 \%$ [14]. The offered technology can decrease its $\mathrm{GHG}$ emissions up to $89.2 \mathrm{MtCO}_{2} \mathrm{Eq}$.

Additional decreasing of GHG emissions expected by the use industrial wastewaters (food, biotechnological etc.) as well as solid other biowastes, unused and expired pharmaceuticals etc. for nutrition of microalgae as well as the use of effluent gases for thermal hydrolyses of solid biowaste, heating and nutrition of microalgae [1]. On other hand, traditional "waste" management represents 1 to $5 \%$ of US GHG emissions [6]. In the U.S. wastewater treatment accounts for $16.7 \%$ of waste emissions and $1.5 \%$ of $\mathrm{N}_{2} \mathrm{O}$ emissions. Therefore the use thermal hydrolyses of active sludge can decrease GHG emissions up to $335 \mathrm{MtCO}_{2} \mathrm{Eq}$.

Seeing $\mathrm{CO}_{2}$ as a raw material and a potential recyclable resource with great value added potential is an excellent example is ENN $110 \mathrm{Mt} \mathrm{CO}_{2} / \mathrm{yr}$ micro-algae pilot plant in China with developed photobioreactors (PBRs) systems for carbon sequestration aimed to the development of algae for biofuels and bioproducts [43]. However this project economic advantage is unknown. On other hand the exhaust steam and effluent gas may be used for heating and aeration of microalgae suspension in biotechnological pools and cultivation microalgae around the year with including of north countries with mitigation of Climate change [1]. In addition the cultivation of microalgae promote also restoration share of $\mathrm{O}_{2}$ due photosynthesis.

Management defined also as human action, including design, to facilitate the production of useful outcomes from a system and managers must understand where and how they can implement offered policies and strategies based on identified also new product candidates. Climate change is a central external driver that affects both water and energy for all uses directly; mitigation measures are concentrated around the reduction of GNG and biofuel manufacturing aimed also to replacing some imported oil by indigenously produced fuels and diversifying sources. Around the world, an urgent demand for alternative, sustainable fuels and feedstock is growing. The most crucial subject in the debate over the sustainability of the $1 \mathrm{G}$ biofuels has intensified over the impact of biofuels on food prices and the merits and structure of biofuels mandates in the U.S. and EU [1,24,25,42,44-47]. The use of agriculture plants for manufacturing of $1 \mathrm{G}$ biofuel could lead to competition for water resources, both in terms of physical availability and access to water, agriculture land availability and food needs will also limit biofuels production based on crops. In Washington, consensus is beginning to emerge that the biofuel RFS in 2013 could actually result in higher net feeding costs for livestock and poultry producers [47] and the EC announces new plans to support domestic advanced biofuels [46]. The EC has vision that all biofuels made from food crops and which do not lead to substantial GNG savings (when emissions from ILUC are included) should not be subsidized in the period after 2020 and represent a further "wildcard", ensure growth in advances biofuels that come from feedstock that is not in competition with food crops. These biofuels also do not pose problems related to increased food prices as they do not come from food crops. In the interim period, the EC proposal aims at stabilizing the consumption of $1 \mathrm{G}$ biofuels. For the fulfillment of the $10 \%$ renewable energy target, the Member States can only count 5\% biofuels from food crops.

What about the cellulosic biofuel? The EC identifies a number of uncertainties associated with the available models and impose sustainability criteria that biofuels and bioliquids which include provisions to prevent the conversion of areas of high biodiversity and carbon sinks such as forest and wetlands [48]. The U.S. definition of cellulosic biomass specifically excludes biomass from federal forests [49]. In 2012 U.S. Beta Renewables (BP) and the Russell cancelled their projects to build a commercial-scale wood biomass power plant based on economical grounds as well as there are protests against their air pollution and the impact that plant would have on the forest [50-52]. Cellulosic biofuel have some potential, but there are significant hurdles to overcome before competitiveness and planned volume is reached [54].

Why are algae so exciting from a renewable energy standpoint? For a summary number application lines and the following reasons [1]: 1) Algae can be processed into biodiesel, bioetanol, jet fuel, and biocrude; 2) Microalgae water consumption of manufacturing is over 10 times as low compared agricultural plants; 3) Algae are generally more efficient converting solar energy due to their simple cellular ultrastructure and immediate access to life support elements such as water, $\mathrm{CO}_{2}$ and nutrients, a higher photon conversion efficiency (approximately 3\% - 8\% against $0.5 \%$ for terrestrial plants which represents higher biomass yields per hectare, according to U.S. National Renewable Energy Laboratory (NPEL) algae can produce at least 10 - 100 times more biomass per hectare in comparison with land plants as well as the oil yields in litters/hectare/year for soybeans are 400 , for palm oil to 6000 and microalgae - a minimum of 60,000 ; 4) Despite several decades of experience in monitoring bioreactors and refining cell culture operations, the production of safe, pure and potent biologics remains a tricky business. In compassion with other microorganisms and plants the microalgae cultivation is more wasteless, ecologically pure, energy and resource saving process. Algae use nutrients more efficiently than land plants. Unlike tradi- 
tional oilseed plants, the amount of pesticide and fertilizer use is virtually eliminated, resulting in less waste and pollution; 5) Microalgae have uniform cell structures with no bark, stems, branches or leaves, allowing easier extraction of products and higher utilization of microalgae cells and their biomass production systems can be easily adapted to various levels of operational and technological skills and the cellular uniformity of microalgae makes it practical to manipulate and control growing conditions for the optimization of cell properties. Microalgae originated value-added co-products or by-products (e.g. proteins, polysaccharides, pigments, biopolymers, animal feed, fertilizers, etc.; 6) Algae are excellent bioremediation agents - they have the potential to absorb massive amounts of $\mathrm{CO}_{2}$ up to 450 tons per acre when grown commercially or over two billion tones of $\mathrm{CO}_{2}$ could be captured by growing algae on the space equivalent to the entire US soybean crop with mitigation of Climate change.

At last years the validity of microalgae approach confirms increasing of quantity of the Microalgae-to-Biofuel projects according to the Biofuel Digest databases [32]. In the Shandong Province of the China under the joint venture of the Australia's Algae. Tec and Shandong Kerui Group Holding Ltd was funded project for the construction of a 250-module algae biofuels facility which will be the first of its size and type in the world with produce approximately 33 million liters of algae derived transport oil and approximately 33,000 tones of biomass per annum at a combined value of over $\$ 40$ million, and capture 137,000 tones of waste carbon dioxide [55]. This project will be additional contribution of other foreign companies in development of microalgae producing in the China [1].

Biotechnology research goals include finding ways to increase the reproductive rate, improve metabolism of inputs, and enhance the production of desired oils, fuel-grade alcohols, proteins and other useful components. Anticipated approaches include improvement of strains through mutation treatment by a physical method (such as ultraviolet irradiation) or a chemical method (such as the use of chemicals). Currently a different and complimentary approach to increase productivity of microalgae is via genetic and metabolic engineering $[1,30$, 56,57]. Genetic engineering techniques are employed to enable algae to more predictably produce desired lipids for biofuels, alcohols, proteins, enzymes and other molecules, or carbohydrate - rich biomass for bioprocessing. Since microalgae may be dispersed by wind or by fauna, open pond systems can introduce algal strains to the surrounding environment. For genetic engineering strain pond systems covered by thin plastic films and combination closed/open systems are being developed to control these factors [30].

A process for production of biofuels from algae can include also cultivating an oil-producing algae in tank and converting the algal oil to biodiesel by promoting sequential photoautotrophic and heterotrophic growth [58]. Genifuel Corporation patents offered to cultivate microalgae in a sugar feed for the production of ethanol by harvesting starch-accumulating filament-forming or colony-forming algae, initiating cellular decay of the biomass in a dark and anaerobic environment, fermenting the biomass in the presence of a yeast, and the isolating the ethanol produced [59]. Solazyme move to manufacture microalgae oils at a cost below $\$ 1000$ per metric ton or $\$ 0.91$ per litter if produced by using the same standard industrial fermenters (128,000-liter) in commercial plant [60].

Economic analysis is an essential evaluation for considering feasibility and viability of large-scale, photo-autotrophic algae-based, biofuel production. The updated cost comparison based on a normalized set of input assumptions was found to greatly reduce economic variability, resulting in algal oil production costs ranging from $\$ 10.87$ gallon $^{-1}$ to $\$ 13.32$ gallon $^{-1}$ [61]. Simultaneously, it was shown that the cost of lipid production to achieve a $10 \%$ return was determined to be $\$ 8.52 /$ gal for open ponds and \$18.10/gal for PBRs [62].

However the development of microalgae-to-biofuels is still in its infancy, there are still many conflicting results and knowledge gaps related to a coupled wastewater treatment and algae cultivation system as well as nowadays studies have demonstrated the feasibility of a coupled system for the treatment of wastewater and cultivation of algae for biofuels only on a small scale and additional lab scale testing is needed to determine the most efficient reactor design and operation methods when using wastewater as a water and nutrient source for algae cultivation as well as issues related to high energy use and cost in PBR and low productivity in open 40 ponds must be resolved in order to determine which system is the most effective as this technology develops in order to effectively couple the algae cultivation [63]. Major challenges to the implementation of an integrated system include the large-scale production of algae and the harvesting of microalgae in a way that allows for downstream processing to produce biofuels and other bioproducts of value according to the patent survey [64] and report on treating municipal and industrial wastewater by using algae which provided detailed descriptions and results for nearly 50 research attempts in the field of algae-based industrial wastewater treatment and lists the companies in algae-based wastewater treatment systems and their profiles [65]. Therefore further investigation and development of large-scale production and harvesting methods of microalgae for biofuels and bio-products are necessary regard to large-scale production of algae include nutrient supply and recycling, gas transfer and exchange, photosynthetically active radiation, delivery, 
culture integrity, environment control, land and water availability, and harvesting [64].

Simultaneously, among the different types of policy tools available, incentives most effectively when linked to production rather than investment [53]. The full processing of microalgae biomass resides decrease cost of manufacturing. Therefore Theory provide cost effective application of microalgae biomass with building product and technology roadmaps, manufacturing of value added products-biofuel, biopharmaceuticals, food, feed and perfumery additives [1]. On other hand in order to achieve approval, microalgae products originated by the use of some waste should satisfy the Safety and International Standards regulating production with avoiding in any case the introduction of heavy metals or cumulative contaminants that could pass to the human chain consumption. Algae Biomass Organisation Technical Standards Committee is tasked on developing and advocating algal industry standards and best practices by providing a framework for evaluating industrial inputs including land, materials, and manpower; outputs including products and waste; and processes and regulations with the industry will interface with the outside world with creating a source of reliable information that can be used by existing standards setting agencies to adapt existing product, testing, and manufacturing standards to the all this new industry. In most cases their clarifications written into existing standards that account for the particular characteristics of the algae industry as a product source [66]. One of obstacle for the implementation product to market is the costs for approval. According to the Algae feed the most relevant entity establishing feed safety international standards is IFIF-International Feed Industry Federation [67]. The FAO responses on test of fish algae supplement based on standard control diet [68]. Other approach is establishing of separate specific standards for each algal product. In 1970s the former USSR was developed All-Union State Standard 22455-77 of the algae feeding meal or groats and All-Union State Standards 64-17-03-87 and 64-17-03-89 for perfumery additives which adopted for CIS countries [1]. Megatro seaweed powder product use China standard Specification Q/ 02MYZ008-2006 [69]. Such approach on development specific standards and Technical Specifications seems as more preferable, can viewed as a more effective means of ensuring that products meet the essential health and safety requirements and provides safeguards against unfair competition, fraud in case of market update of poor quality products from producers and must be applied for strengthen standardisation addressed to speedily introduction of achievements in industry.

\section{Conclusions}

We cannot afford to dismiss any of above listed ap- proaches prematurely. However the possibility of wastewater and watered municipal solid bio-waste use as raw material for manufacturing of microalgae provides that there it has not deficit of raw materials and the process can be implemented on the lands, which is no applicable for agriculture and tanks to transform the concept of waste from one of resource abandonment to a model which all elements along the waste value chain create economic, societal and/or environmental value. The recycling of waste materials by the use of microalgae, and thus the minimizing of the generation of waste are a basic concept which must be implemented in order to meet the new demands of sustainable development. Climate change is not only a major threat, but - in terms of technology - it is a challenge that can give birth to business opportunities based on innovations. Offered sustainable concept and cost effective plan of actions grounded some millions years of the Nature experience and latest findings, are convenient for policymakers, do not require legislative framework which will provide a number of tax grants and support for renewable energy producers, directly contribute to the success of environmental policy and the transition process toward bioeconomy and include global sustainable solution for wastewater management and restoration of water resource, mitigation solid waste and climate change, the improvement in human health through developing cost effective microalgae technologies which increase accessibility of biomass addressed to creation of market opportunities to following competitive products: biofuel, microalgae feed additives (become the best choice for improvement of quality of functional food and cost effective producing animal, poultry and fish with increasing their resistance to diseases), food and perfumery additives and biopharmaceuticals [1]. Our pilot business plan confirms economic viability that the use of microalgae in waste management can decrease cost of feedstock for manufacturing of competitive value added products [1]. Microalgae was the key tool for life development on the earth; at present, algae produce approximately $50 \%-70 \%$ of the atmospheric oxygen and is natural cleaner of global water resource. It is an approved choice of nature. So, there is hope for our offered solutions. Our strategy believes that the use of microalgae will be our adequate answer addressing to unsustainable technological improvements and climate change, thus leading to resolution of global tasks facing the world community through finding of optimum ways for solution of these problems on how to receive raw material for sustainable production with fundamental change of our future.

Fine-tuning a strategy for improving of environment protection depends on many factors, but one thing is clear: Governance, Funds and Companies generally must see the advantage of investing in biotechnological 
game-changing approach, to improve these processes and increasingly look at such investments as economically, environmentally and socially effective impacts. Theory vision will be needed for the development of Global Life Conserve Industry-led Platforms. Who gains from driving forward our vision? The creating of the dominant gap from non efficient protection of environment to its cultivation in a large scale by the use of microalgae will be able to use the windows of opportunity formed by the landscape change toward new design \& build biological system, combined with the prospect of the improvement manufacturing of value added product and will serve future sustainable development of life. The difficulties in realizing all in the time frame of our analysis do not justify inaction or delay, which would raise the long-term economic, security and environmental cost.

\section{REFERENCES}

[1] A. B. Avagyan, "Theory of Global Sustainable Development Based on including of Microalgae in Bio and Industrial Cycles. New Design and Building of Biological Sytem," 2013.

http://www.amazon.com/Theory-Sustainable-Developme nt-including-microalgae/dp/1484000331/ref=pd_rhf_cr_p t_1_5BR4

http://www.amazon.com/Armen-Avagyan/e/B00A7OOIG $\mathrm{G}$

[2] EPA, "Municipal Solid Waste in the U.S.: Facts and Figures," 2011.

http://www.epa.gov/osw/nonhaz/municipal/msw99.htm

[3] EPA, "Municipal Solid Waste Generation, Recycling, and Disposal in the U.S.: Facts and Figures for 2010," 2012. http://www.epa.gov/epawaste/nonhaz/municipal/pubs/ms w_2010_rev_factsheet.pdf

[4] UN, "World Water Development Report (WWDR4)," UNESKO, 2012.

http://www.unesco.org/new/en/natural-sciences/environm ent/water/wwap/wwdr/wwdr4-2012/

[5] EPA, "National Greenhouse Gas Emissions Data," 2011. http://www.epa.gov/climatechange/ghgemissions/usinven toryreport.html

http://www.smartenergyuniverse.com/spotlight/15371-ep a-publishes-18th-annual-u-s-greenhouse-gas-inventory

[6] EPA, "Climate and Waste Statistics," 2013. http://www.epa.gov/climatechange/climate-change-waste/

[7] EEA, "Greenhouse gas Emission Trends and Projections in Europe," 2012.

http://www.eea.europa.eu/publications/ghg-trends-and-pr ojections-2012/at download/file

[8] Pike Research, "Waste-to-Energy Technology Markets," 2012.

http://www.pikeresearch.com/research/waste-to-energy-te chnology-markets

[9] B. Messenger, "European Waste to Energy Technology Market to Hit \$5 Billion," Waste Management World, 2013. http:/www.waste-management-world.com/articles/2013/ 02/european-waste-to-energy-technology-market-to-hit-5billion.html

[10] EC, "Green Paper on the Management of Bio-Waste in the European Union. Climate Change and Food Systems," $\operatorname{COM}(2008) 811$ final. \{SEC(2008) 2936\} (2008), 2008. http://eur-lex.europa.eu/LexUriServ/LexUriServ.do?uri= COM:2008:0811:FIN:EN:PDF

[11] Confederation of European waste-to-energy plants, "Recycling and Waste-to-Energy in Combination for Sustainable Waste Management," 2012.

http://www.cewep.eu/m_1038

Energy Report III. 2012. http://www.cewep.eu/m_1069

[12] J. Ewald, "Carbon Dioxide at NOAA's Mauna Loa Observatory Reaches New Milestone: Tops 400 ppm,” 2013. http://icecap.us/index.php/go/joes-blog/in_defense_of_car bon_dioxide/https://scripps.ucsd.edu/news/7992 https://scripps.ucsd.edu/news/7992

[13] EPA, "Global Greenhouse Gas Emissions Data," 2005. http://www.epa.gov/climatechange/ghgemissions/global.h tml

[14] Emergent Waste Solutions, "Mergent Waste Solutions Deploys the Unique APS ${ }^{\circledR}$ Technology, Capable of Answering the Global Challenge of Waste Disposal," 2013. http://www.emergentwastesolutions.com

[15] A. Bennett, "Wastewater Treatment and Energy Production," Filtration \& Separation, Vol. 44, No. 10, 2007, pp. 16-19. http://dx.doi.org/10.1016/S0015-1882(07)70319-1

[16] Solid Waste Association of North America, "Waste-toEnergy Facilities Provide Significant Economic Benefits," 2012.

http://swana.org/portals/Press_Releases/Economic_Benef its_WTE_WP.pdf

[17] D. Hoornweg, "Talking Heads. Megacities," Waste Management World, 2012, p. 66.

$\mathrm{http}: / /$ delivery.qmags.com/d/?pub=WMW\&upid=16794\& $\mathrm{s}=\mathrm{OL} \& \mathrm{fl}=$ others $\% 2 \mathrm{fWMW} \% 2 \mathrm{fWMW} 20120301 \_$Mar_2 012.pdf http://online.qmags.com/WMW0312\#pg1\&mode2

[18] SBI Bulletin, "Waste to Energy Markets to Grow 11.2\% Annually Through 2021," 2012. http://www.sbireports.com/about/release.asp?id=2872

[19] Environmental Expert, "2nd Annual Waste Conversion Congress East Coast 2012,” 2012.

http://www.environmental-expert.com/events/2nd-annualwaste-conversion-congress-east-coast-2012-12734

[20] D. Kiernan, "Waste to Biofuels Set for Growth But Industry Must Remain Realistic." Waste Management World, 2012.

http://www.alternativeoutlook.co.uk/2012/05/waste-to-bi ofuels-set-for-growth-but-industry-must-remain-realistic/ http://www.waste-management-world.com/articles/2012/ 05/waste-to-biofuels-set-for-growth-but-industry-must-re main-realistic.html

[21] V. R. Surisetty, J. Kozinski and A. K. Dalai, "Biomass, Availability in Canada, and Gasification: An Overview," Biomass Conversion and Biorefinery, Vol. 2, No. 1, 2012, pp. 73-85. http://dx.doi.org/10.1007/s13399-011-0024-0

[22] P. French, M. Cuddeford and J. A. Cody, "Waste to En- 
ergy: Investment Landscape. Renewable Waste Markets Report 2012-13," 2012.

http://www.renewable-waste.com/markets-report/pdf/WC $\mathrm{T}$-Investment-Landscape-Whitepaper.pdf?utm source $=\mathrm{htt}$ p $\% 3 \mathrm{a} \% 2 \mathrm{f} \% 2$ fus.renewable-waste.com $\% 2 \mathrm{ffc}$ f fcbi1lz $\% 2 \mathrm{f}$ \&utm_medium $=$ email\&utm_campaign $=2144+\% 2 b+$ Whit epaper+BD\&utm_term $=$ Your + complimentary + renewable + waste + investment + landscape + analysis\&utm_content $=2$ 39408

[23] M. Chrusciak, "European Waste to Energy Plant Market," 2013.

http://www.frost.com/sublib/display-report.do?searchQue $\mathrm{ry}=$ Monika + Chrusciak\&id=M8EE-01-00-00-00\&bdata $=\mathrm{a}$ HR0cDovL3d3dy5mcm9zdC5jb20vc3JjaC9jYXRhbG9n LXN1YXJjaC5kbz9xdWVyeVRleHQ9TW9uaWthK0Noc nVzY2lha0B\%2BQFNIYXJjaCBSZXN1bHRzQH5AMT M3MTE5NzE5MjUxMQ\%3D\%3D

[24] A. B. Avagyan, "A Contribution to Global Sustainable Development: Inclusion of Microalgae and Their Biomass in Production and Bio Cycles", Clean Technologies and Environmental Policy, Vol.10, No. 4, 2008, pp. 313-317. http://dx.doi.org/10.1007/s10098-008-0180-5

[25] A. B. Avagyan, "New Design \& Build Biological System Addressed to Global Environment Management and Sustainable Development through including Microalgae and Their Biomass in Production and Bio Cycles," Journal of Environmental Protection, Vol. 1, No. 2, 2010, pp. 183-200. http://dx.doi.org/10.4236/jep.2010.12023

[26] International Renewable Energy Agency, "Evaluating Policies in Support of the Deployment of Renewable Power," Abu Dhabi, United Arab Emirates, 2012. http://www.irena.org/DocumentDownloads/Publications/ Evaluating_policies_in_support_of_the_deployment_of_r enewable_power.pdf

[27] P. J. van der Aar, "Biofuels: Implications for the Feed Industry," In: J. Doppenberg and Piet van der Aar, Eds., Biofuels, 2007, pp. 11-13,

http://www.contextbookshop.com/books/book_detail.php ?bookcat $=17$ \&bookid $=171$.

[28] M. Briggs, "Widescale Biodiesel Production from Algae," University of New Hampshire, 2004. http://web.archive.org/web/20060324084858/http://www. unh.edu/p2/biodiesel/article_alge.html

[29] J. Sheehan, T. Dunahay, J. Benemann and P. Roessler, "A Look Back at the US Department of Energy's Aquatic Species Program: Biodiesel from Algae," 2006. http://www1.eere.energy.gov/biomass/pdfs/biodiesel_fro m_algae.pdf.

[30] T. J. Lundquist, I. C. Woertz, N. W. T. Quinn and J. R. Benemann, "A Realistic Technology and Engineering Assessment of Algae Biofuel Production," Berkeley: Report of Energy Biosciences Institute University of California, 2010. http://esd.lbl.gov/files/about/staff/nigelquinn/EBI_Algae_ Biofuel_Report_2010.10.25.1616.pdf

[31] Oilgae, "Energy from Algae, products, market, processes, strategies. Algae Oil Information," Comprehensive Report, 2008. http://www.oilgae.com/algae/oil/oil.html

[32] J. Lane, “Advanced Biofuels Tracking Databases," Biofuels Digest, 2010-2012. http://www.biofuelsdigest.com/bdigest/2010/03/23/advan ced-biofuels-tracking-database/

http://biofuelsdigest.com/bdgest/2011/01/14/10-advanced -biofuelsprojects-now-planned-in-advanced-biofuels/ http://www.google.com.br/url?sa=t\&rct=j\&q=advanced $\%$ 20biofuels\%20project $\% 20$ database $\% 20$ (release $\% 202.04$ ) $\&$ source $=$ web\&cd $=8 \&$ ved $=0$ CGEQFjAH\&url $=$ http $\% 3 \mathrm{~A}$ $\% 2 \mathrm{~F} \% 2 \mathrm{Fwww}$.ascension-publishing.com $\% 2 \mathrm{FBIZ} \% 2 \mathrm{FA}$ BTDv204.xls\&ei=MoqET7yXBsnGtAaUwem1Bg\&usg= AFQjCNFET9UBdZzRqotWaKUsGv9X0XuIoQ)

http://www.google.com/url?sa=D\&q=http://www.biofuels digest.com/bdigest/wp-content/uploads/2012/07/ABPD-Q 312.xls\&usg=AFQjCNEZi8bLKw1g5KB81Rf6WWLW8 2_LzQ

[33] K. Bullis, "NASA Wants to Launch Floating Algae Farms," Technology Review, MIT, 2012. http://www.technologyreview.com/energy/40120/page1/

[34] E. Gagnon, "Pharmaceutical Disposal Programs for the Public: A Canadian Perspective," Health Canada Environmental Impact Initiative, 2009. http://www.enviroadvisory.com/pdf/Takeback.pdf

[35] EU "Directive 2001/83/EC of the European Parliament and of the Council of 6 November 2001 on the Community Code Relating to Medicinal Products for Human Use," Official Journal L 311, pp. 67

http://eur-lex.europa.eu/LexUriServ/LexUriServ.do?uri= CONSLEG:2001L0083:20070126:en:PDF

[36] N. Savransky, "Pharmaceuticals in the Water. A Look at an Emerging and Pressing Issue," 2012. http://www.mass.gov/dep/toxics/stypes/pharmh2o.pdf

[37] J. Gunderson, "Water Treatment: Chemical and Pharmaceutical Industries," Water World, Vol. 12, No. 5, 2012, p. 5. http://www.waterworld.com/articles/iww/print/volume-12 /issue-05/feature-editorial/water-treatment-chemical-andpharmaceutical-industries.html

[38] J. Gustavsson, C. Cederberg, U. Sonesson and R. O. A. Meybeck, "Global Food Losses and Food Waste Extent, Causes and Prevention," FAO, 2011. http://www.fao.org/docrep/014/mb060e/mb060e00.pdf

[39] EPA, “Opportunities to Reduce Greenhouse Gas Emissions through Materials and Land Management Practices," 2009.

http://www.epa.gov/oswer/docs/ghg_land_and_materials management.pdf

[40] EEA, "Annual European Union Greenhouse Gas Inventory 1990-...2011 and Inventory Report 2013," 2013. http://www.eea.europa.eu/publications/european-union-gr eenhouse-gas-inventory-2013

[41] Food Use for Social Innovation by Optimising Waste Prevention Strategies, “About Food Waste," 2013. http://www.eu-fusions.org/about-food-waste

[42] International Energy Agency, "World Energy Outlook," OECD/IEA, Paris, 2006.

http://www.iea.org/publications/freepublications/publicati on/weo2006.pdf

[43] G. Sun, "US-China Cooperative Work on Carbon Capture, Use and Storage," US-China Energy Centre, 2012. http://www.egcfe.ewg.apec.org/publications/proceedings/ CFE/Austrailia_2012/2A-3_Sun.pdf 
[44] OPEC, "World Oil Outlook," 2008.

http://www.opec.org/opec_web/static_files_project/media /downloads/publications/WOO\%202008.pdf

[45] R. Troustle, D. Marti, S. Rosen and P. Westcott, "Why Have Food Commodity Prices Risen Again?” USDA, 2012. http://www.ers.usda.gov/media/126752/wrs1103.pdf http://www.national-economists.org/gov/trostle11.pdf

[46] EC, "Indirect Land Use Change (ILUC)," MEMO/12/787, 2012.

http://europa.eu/rapid/press-release_MEMO-12-787_en.ht $\mathrm{m}$ ?locale $=\mathrm{en}$

[47] J. Lane, "RFS Waiver Could Raise Feed Costs for Livestock, Dairy Producers: New Study," Biofuels Digest, 2012. http://www.biofuelsdigest.com/bdigest/2012/10/11/rfs-wa iver-could-raise-feed-costs-for-livestock-dairy-producersnew-study/

[48] EC, "Biofuels: Commission Adopts Report on Indirect Land Use Change," Europe Press Releases, 2010. $\mathrm{http} / /$ europa.eu/rapid/pressReleasesAction.do?reference= IP/10/1772\& format $=$ HTML\&aged $=0$ \&language $=$ EN\&gu iLanguage $=$ en

[49] K. Bracmor, R. Schnepf, M. Stubbs and B. D. Yacobucci, "Cellulosic Biofuels: Analysis of Policy Issues for Congress," 2010.

http://www.nationalaglawcenter.org/assets/crs/RL34738.p df

[50] J. Lane, "The October Surprise: BP Cancels Plans for US Cellulosic Ethanol Plant," Biofuels Digest, 2012. http://www.biofuelsdigest.com/bdigest/2012/10/26/the-oc tober-surprise-bp-cancels-plans-for-us-cellulosic-ethanolplant/

[51] M. Cichon, "Russell Biomass Plant Cancelled: The Start of an Industry Trend?" Renewable Energy World, 2012. http://www.renewableenergyworld.com/rea/news/article/2 012/10/russell-biomass-plant-cancelled-the-start-of-an-in dustry-trend?cmpid=BioNL-Tuesday-October30-2012

[52] T. LaBorde, "Russell Biomass Power Plant Partners Cancel Project," Mass Live, 2012.

http://www.masslive.com/news/index.ssf/2012/10/partner s_in_russell_biomass_po.html

[53] U.S. Energy Information Administration, "Biofuels Issues and Trends," U.S. Department of Energy, 2012. http://www.eia.gov/biofuels/issuestrends/pdf/bit.pdf

[54] International Energy Agency, "World Energy Outlook," OECD/IEA, Paris, 2011, 660p.

http:/www.worldenergyoutlook.org/media/weowebsite/2 011/weo2011_energy_for_all.pdf

[55] Admin, "Algae.Tec, Shandong Kerui for Algal Biofuels JV in China," Biofuel Dighest, 2012.

http:/www.biofuelsdigest.com/bdigest/2012/01/19/algaetec-shandong-kerui-for-algal-biofuels-jv-in-china/

[56] Y. Chisti, "Biodiesel from Microalgae Beats Bioethanol," Trends in Biotechnology, Vol. 26, No. 3, 2008, pp. 126131. http://www.massey.ac.nz/ ychisti/Trends08.pdf

[57] R. Radakovits, R. E. Jinkerson, A. Darzins and M. C. Posewitz, "Genetic Engineering of Algae for Enhanced Biofuel Production," Eukaryotic Cell, Vol. 9, No. 4, 2010, 486-501. http://dx.doi.org/10.1128/EC.00364-09
[58] SciTech Patent Art Patent Tracker, "Patenting Trends in Algae Based Biofuels," Hyderabad, 2013.

http://www.patent-art.com/NewsImages/nw12/PatentingT rendsinAlgaebasedBiofuels.pdf

[59] Genifuel Corporation, "Integrated Processes and Systems for Production of Biofuels Using Algae," US patent No. 7977076 B2, 2011.

http://www.google.com/patents/US7977076?printsec=abs tract\&dq=ininventor:\%22James+R.+Oyler\%22\&ei=Ujk8 UYmoMs3MPbrzgPgO\#v=onepage\&q\&f=false; "Process of Producing Oil from Algae Using Biological Rupturing," US Patent No. US20120285077 A1, 2012.

http://www.google.com/patents/US20120285077?dq=inin ventor:\%22James + R. + Oyler $\% 22 \& h l=e n \& s a=X \& e i=D j Y$ 8UZOqAsKkO82GgJAL\&ved=0CDkQ6AEwAQ

[60] J. Lane, "Solazyme Files Its Expected IPO, But in Its S-1 Are Unexpected Progress on Costs, Capacity, and a Surge of Offtake Orders; But Can the Company Make Oil Fast Enough to Meet the Demand and Capture All the Opportunities?" Biofiel Dighest, 2011.

http://www.biofuelsdigest.com/bdigest/2011/03/15/solazy me-files-100m-ipo/

[61] A. Sun, R. Davis, M. Starbuck, A. Ben-Amotz, R. Pate and P. T. Pienkos, "Comparative Cost Analysis of Algal Oil Production for Biofuels," Energy, Vol. 36, No. 8, 2011, pp. 5169-5179. http://dx.doi.org/10.1016/j.energy.2011.06.020

[62] R. Davis, A. Aden and P. T. Pienko, "Techno-Economic Analysis of Autotrophic Microalgae for Fuel Production," Applied Energy, Vol. 88, No. 10, 2011, pp. 3524-3531. http://dx.doi.org/10.1016/j.apenergy.2011.04.018

[63] M. C. Rothermel, "Coupling the Wastewater Treatment Process with an Algal Photobioreactor for Nutrient Removal and Renewable Resource Production," University of Pittsburgh, Pittsburgh, 2011.

http://d-scholarship.pitt.edu/8395/1/RothermelMonicaSu mmer2011.pdf

[64] L. Christenson and R. Sims, "Production and Harvesting of Microalgae for Wastewater Treatment, Biofuels, and Bioproducts," Biotechnology Advances, Vol. 29, No. 6, 2011, pp. 686-702. http://dx.doi.org/10.1016/j.biotechadv.2011.05.015

[65] Oligae, "Oligae Guide to Algae-Based Waste- water Treatment," 2010.

http://www.oilgae.com/ref/downloads/Wastewater_Treat ment_Using_Algae_Report_Preview.pdf

[66] ABO, "Algae Industry Minimum Descriptive Language: Guidance to Evaluate Life Cycle Inputs and Outputs," Technical Standards Committee, 2012. http://www.algaebiomass.org/wp-content/uploads/2012/0 9/ABO-MDL-5.0-WEB-VERSION-Sept-2012.pdf

[67] Algae4feed, 2013. http://www.algae4feed.org/

[68] FAO, “Algae," FAO, 2013. http://www.fao.org/docrep/012/i1141e/i1141e01.pdf

[69] Megatro, 2013. http://www.ttnet.net/ttnet/gotoprd/CC240/020/0/1383639 383831343633363435303539303038323634313.htm 